\title{
Spatial and temporal distribution of ambient nitric acid and ammonia in the Athabasca Oil Sands Region, Alberta
}

\author{
Andrzej BYTNEROWICZ*, Witold FRACZEK ${ }^{1)}$, Susan SCHILLING and Diane ALEXANDER \\ USDA Forest Service, Pacific Southwest Research Station, 4955 Canyon Crest Drive, Riverside, CA 92507, USA \\ 1) Environmental Systems Research Institute, 380 New York Street, Redlands, CA 92373, USA \\ *e-mail corresponding author: abytnerowicz@fs.fed.us
}

ABSTRACT

Monthly average ambient concentrations of gaseous nitric acid $\left(\mathrm{HNO}_{3}\right)$ and ammonia $\left(\mathrm{NH}_{3}\right)$ were monitored at the Athabasca Oils Sands Region (AOSR), Alberta, Canada, between May 2005 and September 2008. Generally, concentrations of both pollutants were elevated and highly variable in space and time. The highest atmospheric concentrations occurred in the vicinity of the major mining and oil extraction activities of Fort Murray and Fort McKay. Maximum monthly average concentrations of $\mathrm{HNO}_{3}$ decreased from $>6 \mu \mathrm{g} \mathrm{m}^{-3} 2005$ and 2006 to $<4 \mu \mathrm{g} \mathrm{m}^{-3}$ in 2007 and 2008. While the $\mathrm{HNO}_{3}$ summer seasonal averages in 2005 and 2006 approached $\sim 2 \mu \mathrm{g} \mathrm{m}^{-3}$ at some sites, in the subsequent summers and during winter seasons it rarely exceeded $1 \mu \mathrm{g} \mathrm{m} \mathrm{m}^{-3}$ and no clear differences between summer and winter occurred. Concentrations of $\mathrm{NH}_{3}$ were elevated during the entire study and frequently reached $6 \mu \mathrm{g} \mathrm{m}^{-3}$. Generally, $\mathrm{NH}_{3}$ stayed higher in summer than in winter; the summer seasonal averages often exceeded $4 \mu \mathrm{g} \mathrm{m}^{-3}$ while those for winter only on two occasions were above $3 \mu \mathrm{g} \mathrm{m}^{-3}$. In summer 2008, an expansion of the area with elevated $\mathrm{NH}_{3}$ levels was observed extending to remote locations. Ammonia is of a much higher concern from a perspective of possible biological effects, because of its potential for direct toxic effect on lichens and its contribution to the elevated $N$ dry deposition with possible negative consequences for forests and other ecosystems.

Key words: air pollution, passive samplers, nitrogen deposition, boreal forests, potential phytotoxic effects, Canada

\section{INTRODUCTION}

The Athabasca Oil Sands Region (AOSR) is located in the north-eastern part of Alberta, Canada, and contains large deposits of oil in a form of naturally occurring heavy molecular weight hydrocarbons of high viscosity, called bitumen, which are mixed with clay, sand and water. The AOSR deposits are the largest of three major oil sands deposits in Alberta, along with the nearby Peace River and Cold Lake areas (Fig. 1). These three oil sand deposits lie beneath $141,000 \mathrm{~km}^{2}$ of a sparsely populated boreal forest and muskeg, and contain 1.7 trillion barrels $\left(270 \times 10^{9} \mathrm{~m}^{3}\right)$ of bitumen (Kean 2009). With modern non-conventional oil production technology at least $10 \%$ of these deposits were considered to be economically recoverable at the 2006 prices making Canada's oil reserves the second largest in the World, after Saudi Arabia (Kunzig 2009). Since 2003, as a result of rapid increases of oil prices, the mining and extraction activities have been greatly expanded and new facilities are being planned-while the current production is 1.3 million barrels daily, it is projected to reach 3 million barrels $\left(477,000 \mathrm{~m}^{3}\right)$ per day by 2018 (Kean 2009).

The large scale of oil extraction operations at the AOSR is energy intensive and causes numerous environmental problems, among them emissions of greenhouse gases and toxic air pollutants (Charpentier et al. 2009). Major sources of air pollutants in the
AOSR are associated with the open-pit mining, bitumen separation from sand and clay, steam assisted gravity drainage, cystic steam stimulation, upgrading and transformation of oil from bitumen into a high quality synthetic crude oil using variations of the Clark Hot Water Extraction method (Gu et al. 2002). Other important sources of air pollutants are exhausts from numerous trucks and other types of machinery used in mining and transportation of bitumen ore as well as emissions of vapours from the tailing ponds (Kelly et al. 2009). Air pollutants associated with health and environmental concerns in the AOSR are the criteria pollutants such as ozone $\left(\mathrm{O}_{3}\right)$, sulphur dioxide $\left(\mathrm{SO}_{2}\right)$, nitrogen oxides $\left(\mathrm{NO}_{\mathrm{x}}\right)$, as well as other pollutants such as nitric acid $\left(\mathrm{HNO}_{3}\right)$, ammonia $\left(\mathrm{NH}_{3}\right)$, carbon monoxide $(\mathrm{CO})$, particulate matter measured as $\mathrm{PM}_{2.5}$ and $\mathrm{PM}_{10}$, and total hydrocarbons (THC). The Wood Buffalo Environmental Association (WBEA) has been responsible for ambient air quality monitoring in this area using both continuous monitors and passive samplers.

Ammonia and $\mathrm{HNO}_{3}$ are important components of reactive atmospheric nitrogen $(\mathrm{N})$ and major drivers of atmospheric $\mathrm{N}$ dry deposition to forests and other ecosystems (Hanson \& Lindberg 1991; Lovett 1994; Magnani et al. 2009). Nitric acid is a final product of oxidation of $\mathrm{NO}_{\mathrm{x}}$ emitted during fossil fuel combustion, forest fires, and other natural and anthropogenic processes (Finlayson-Pitts \& Pitts 2000). Ammonia emissions are caused by agricultural activities, 


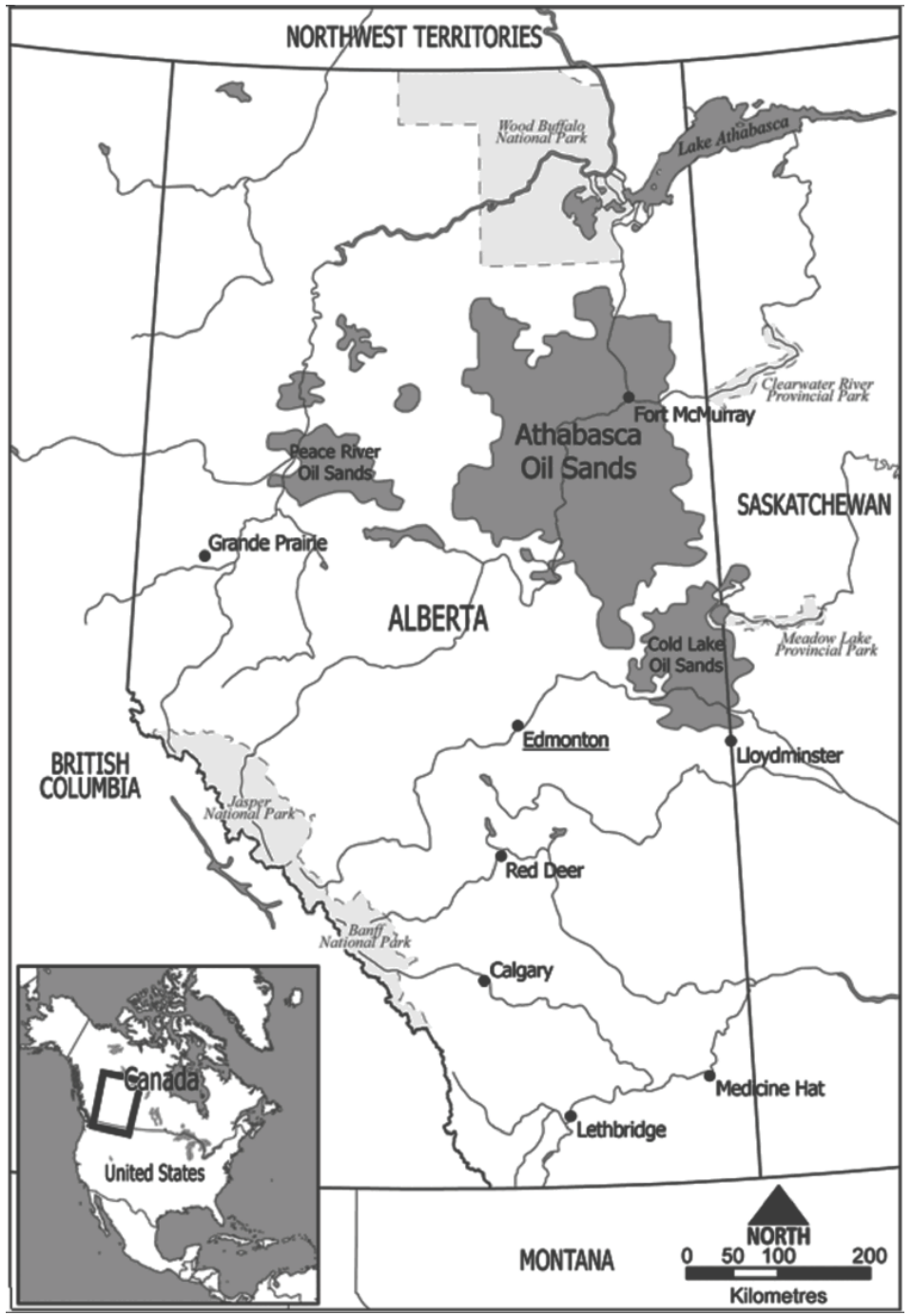

Fig. 1. Location of the Athabasca Oils Sands Region in Alberta, Canada (after URL: en.wikipedia.org/wiki/File:Athabasca_Oil_ Sands_map.png).

biological decay processes, catalytic converters, the smouldering phase of fires, and other activities (Krupa 2003). Both $\mathrm{HNO}_{3}$ and $\mathrm{NH}_{3}$ are potentially phytotoxic at high ambient concentrations, and their toxicity may be enhanced at low temperatures when rates of the biochemical detoxification mechanisms in plants are low (Bytnerowicz et al. 1998). Recently developed passive samplers for $\mathrm{HNO}_{3}$ and $\mathrm{NH}_{3}$ are simple to use, inexpensive, do not require electricity or air conditioned shelters and can be used in remote locations (Krupa \& Legge 2000). As such, passive samplers allow for an improved spatial coverage of the areas of interest providing data that can be used for generation of geostatistical maps of air pollutant distributions.

The rapidly growing bitumen mining, oil recovery and processing, as well as the spatial expansion of the oil sands exploitation area have increased the emissions of air pollutants in the AOSR. Consequently, there has been a growing concern that ambient concentrations of air pollutants could increase to the levels which can have negative effects on ecosystems. This concern has resulted in a need for more extensive monitoring of the key air pollutants, including $\mathrm{HNO}_{3}$ and $\mathrm{NH}_{3}$. Since these two pollutants are important components of atmospheric dry $\mathrm{N}$ deposition, they may potentially have negative impacts on forests, wetlands and lakes in the AOSR. These effects may be numerous and complex, including acidification of lakes and streams, contamination of water with nitrate $\left(\mathrm{NO}_{3}{ }^{-}\right)$and ammonium $\left(\mathrm{NH}_{4}{ }^{+}\right)$, euthrophication of bogs, fens and meadows, changing composition of the vegetation community, direct toxic effects of pollutants on lichen communities, and many others (Fenn et al. 2003; U.S. EPA 2009).

The main objective of this study was to characterize the spatial and temporal distribution of $\mathrm{HNO}_{3}$ and $\mathrm{NH}_{3}$ in the AOSR from a perspective of their potential biological effects. The secondary objective was to provide information needed for future optimization of the air pollution monitoring network. 

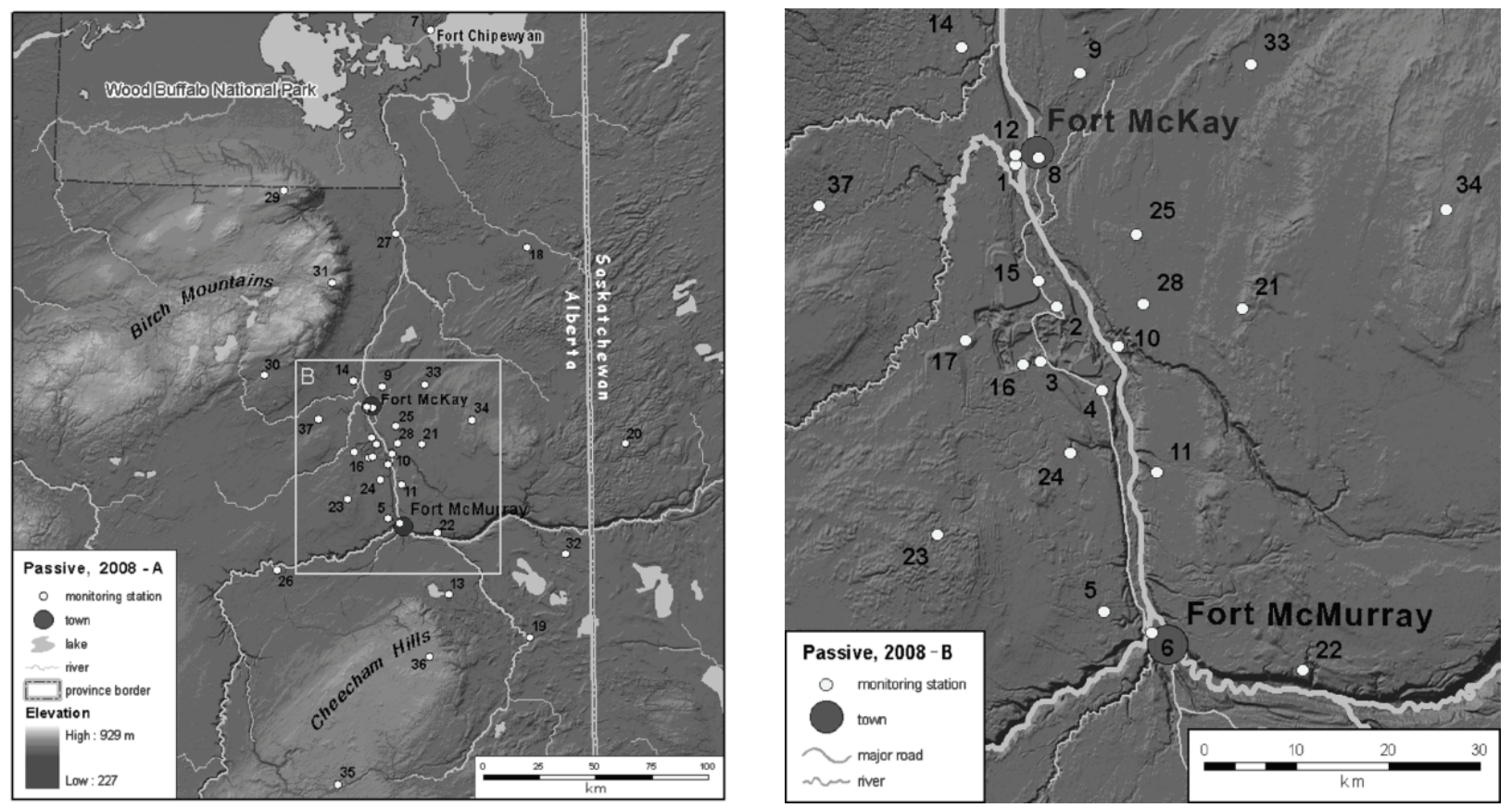

Fig. 2. (A) General map of $\mathrm{HNO}_{3}$ and $\mathrm{NH}_{3}$ passive sampler monitoring network in the Athabasca Oils Sands Region as of the 2007/2008 winter and 2008 summer seasons; (B) close up of the central area of the monitoring network. Numbers on the maps correspond to sites listed in table 1 and 2 .

\section{METHODS}

\subsection{Passive samplers}

A network of passive samplers was established for monitoring integrated, month-long, concentrations of $\mathrm{HNO}_{3}$ and $\mathrm{NH}_{3}$. The initial network developed in 2005 consisted of the passive sampler sites collocated with 14 ambient air quality monitoring stations and 11 remote forest health assessment sites. Gradually the network grew to 37 sites in 2008 (Fig. 2a, b), and in September 2008 covered the area of about 320 by $160 \mathrm{~km}(\sim 51,000$ $\mathrm{km}^{2}$ ). There were three major groups of monitoring sites: 'local', where the passive samplers were collocated with the continuous monitoring equipment; 'remote' at the forest research sites, and 'lakes' at the limnological research sites. At the 'remote' sites samplers were located above forest canopy at about $10 \mathrm{~m}$ from the ground on towers specially designed for passive samplers. At all other sites the samplers were placed on wooden posts about $2 \mathrm{~m}$ above the ground level. In summer 2008 at the remote site B213, in addition to the regular samplers positioned above the forest canopy, samplers were also placed beneath the canopy at $0.5,1$ $\mathrm{m}$ and $2 \mathrm{~m}$ above the ground to evaluate vertical distribution of the pollutants. Three replicate $\mathrm{HNO}_{3}$ samplers of the USDA Forest Service design (Bytnerowicz et al. 2005) were used at each monitoring site. In these samplers, ambient air passes through a Teflon membrane and gaseous $\mathrm{HNO}_{3}$ is absorbed on a Nylasorb nylon filter as nitrate $\left(\mathrm{NO}_{3}{ }^{-}\right)$. Nylon filters from the samplers were extracted in nano-pure water, and $\mathrm{NO}_{3}{ }^{-}$concentrations in filter extracts were analyzed by ion chromatography (Dionex ICS 2000 LCD). Average ambient $\mathrm{HNO}_{3}$ concentrations were calculated using calibration curves developed by comparing the passive samplers against the collocated annular denuder systems (Koutrakis et al. 1993). In the field trials performed in Riverside, California, the samplers showed high accuracy (relative standard deviation of three replicate readings of $\sim 5 \%$ ). Passive samplers of the Ogawa design (Roadman et al. 2003) were used for $\mathrm{NH}_{3}$ monitoring with two replicate filters coated with citric acid. Ammonia reacts with citric acid on the filters producing ammonium citrate. After water extraction, $\mathrm{NH}_{4}^{+}$concentrations in filter extracts were determined colourimetrically on a TRAACS 2000 Autoanalyzer, and ambient $\mathrm{NH}_{3}$ concentrations were calculated based on a comparison of passive samplers against the collocated annular denuder systems (Koutrakis et al. 1993). The accuracy of the samplers tested during field trials performed in Riverside, California, was high (relative standard deviation of four replicate readings $\sim 4 \%$ ). In this paper we report results for the period May $1^{\text {st }}, 2005$ through to September $30^{\text {th }}, 2008$. Both $\mathrm{HNO}_{3}$ and $\mathrm{NH}_{3}$ passive samplers were changed every month between May $1^{\text {st }}$ through October $31^{\text {st }}$, and every 2 months between November 1 and April 30. Four blank $\mathrm{HNO}_{3}$ filters and four blank $\mathrm{NH}_{3}$ filters were used for each exposure period. Blank samples were kept in closed containers located in chemical laboratory of the US Forest Service, Riverside, California. For the entire study, the average relative standard deviation values for the $\mathrm{HNO}_{3}$ and $\mathrm{NH}_{3}$ field-exposed samplers were $12.9 \%$ and $12.6 \%$, respectively. 

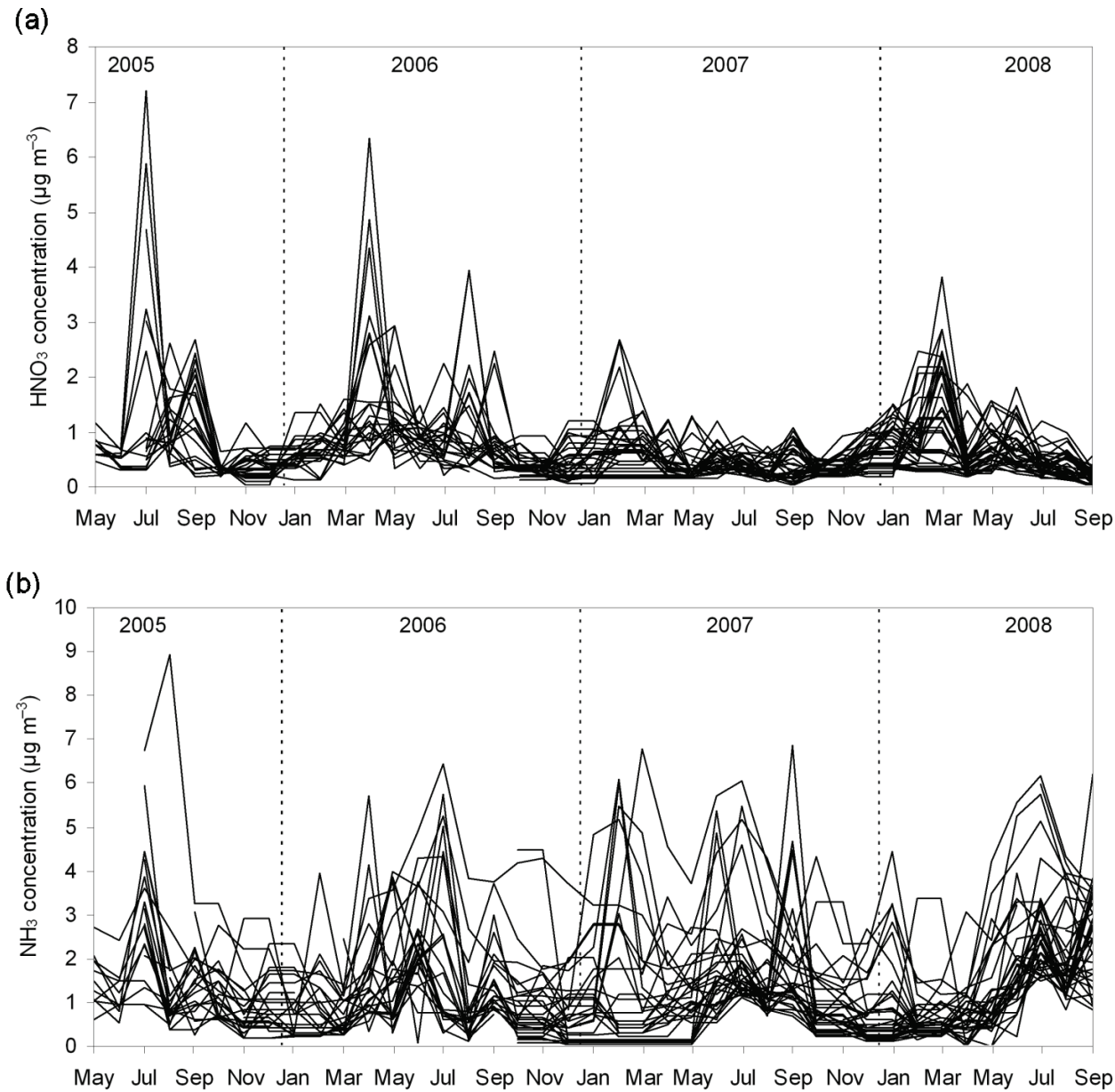

Fig. 3. Monthly average $\mathrm{HNO}_{3}$ (a) and $\mathrm{NH}_{3}$ (b) concentrations in the Athabasca Oils Sands Region between May 2005 and September 2008 for all sites $(\mathrm{n}=37)$.

\subsection{Geostatistical analysis}

Pollutant distribution maps were developed with the Geostatistical Analyst, extension of ArcGIS software (ESRI, Redlands, CA). The Geostatistical Analyst uses values measured at sample points at different locations in the landscape and interpolates them into a continuous surface. The spatial distribution of $\mathrm{NH}_{3}$ and $\mathrm{HNO}_{3}$ were based on averages of 6 monthly pollutant concentrations at 37 sites using an inverse distance weighting method (Johnston et al. 2001). The uncertainty of prediction, called the prediction standard error map, was calculated using simple kriging with a 'normal score' transformation type. The numerical values were calculated to represent two standard deviations, or the $95 \%$ confidence level (Chiles \& Delfiner 1999). With this, 95\% of the time the true value of the prediction (represented by the map of prediction) is within the interval formed by the predicted value \pm the relevant prediction standard error. Levels of uncertainty are shown as shades starting from light (lowest uncertainty of prediction) to dark (highest uncertainty).

\section{RESULTS}

\subsection{Pollutant levels and distribution}

Nitric acid concentrations expressed as monthly averages during the entire study between May 2005 and September 2008, were highly variable both spatially and temporally (Fig. 3, Tab. 1). The highest concentrations exceeding $7 \mu \mathrm{g} \mathrm{m}^{-3}$ in July 2005 occurred at site AMS 10T and $6.5 \mu \mathrm{g} \mathrm{m}^{-3}$ at site PH2 in April 2006; since then the $\mathrm{HNO}_{3}$ concentrations were $<4 \mu \mathrm{g} \mathrm{m}{ }^{-3}$. No clear trends of seasonal patterns were observed, in some years the summer values were higher (2005 and 2006) while in other (2007 and 2008) the winter levels were higher (Fig. 3, Tab. 1). Measurement performed on a vertical gradient at Site B213 in summer 2008 showed that $\mathrm{HNO}_{3}$ at 0.5 and $1 \mathrm{~m}$ above the ground was much lower $\left(0.18\right.$ and $0.13 \mu \mathrm{g} \mathrm{m}^{-3}$, respectively) than at $2 \mathrm{~m}$ above the ground and above the canopy $\left(0.44\right.$ and $0.45 \mu \mathrm{g} \mathrm{m}^{-3}$, respectively). The 2007/2008 winter and 2008 summer data were chosen as the examples of $\mathrm{HNO}_{3}$ spatial distribution (Fig. 4a, b). The geostatistical maps pre- 
Tab. 1. Atmospheric $\mathrm{HNO}_{3}$ concentrations $\left(\mu \mathrm{g} \mathrm{m}^{-3}\right.$ ) for summer and winter seasons during the 2005-2008 monitoring period expressed as average (and standard deviation). In general seasonal averages are based on six observations, average values without a standard deviation are based on one observation.

\begin{tabular}{|c|c|c|c|c|c|c|c|c|}
\hline \multirow[t]{2}{*}{ ID } & \multirow[t]{2}{*}{ Site name } & \multicolumn{2}{|c|}{2005} & \multicolumn{2}{|c|}{2006} & \multicolumn{2}{|c|}{2007} & \multirow{2}{*}{$\begin{array}{c}2008 \\
\text { Summer }\end{array}$} \\
\hline & & Summer & Winter & Summer & Winter & Summer & Winter & \\
\hline 1 & AMS 01-L & $1.50(1.00)$ & $0.58(0.44)$ & $1.10(0.70)$ & $0.48(0.32)$ & $0.48(0.21)$ & $1.03(0.96)$ & $0.70(0.43)$ \\
\hline 2 & AMS 02-L & $1.34(0.59)$ & $0.71(0.46)$ & $1.09(0.39)$ & $0.88(0.33)$ & $0.67(0.36)$ & $0.90(0.46)$ & $0.61(0.24)$ \\
\hline 3 & AMS 04-L & $1.07(0.76)$ & $0.52(0.31)$ & $0.97(0.53)$ & $0.48(0.18)$ & $0.46(0.21)$ & $1.09(0.64)$ & $0.47(0.15)$ \\
\hline 4 & AMS 05-L & $0.59(0.26)$ & $0.68(0.45)$ & $1.75(1.46)$ & $0.71(0.34)$ & $0.57(0.23)$ & $1.36(1.25)$ & $0.58(0.32)$ \\
\hline 5 & AMS 06-L & $1.17(0.87)$ & $0.63(0.27)$ & $1.12(0.50)$ & $0.64(0.18)$ & $0.46(0.29)$ & $0.99(0.62)$ & $0.73(0.54)$ \\
\hline 6 & AMS 07-L & $1.37(1.10)$ & $0.53(0.13)$ & $0.98(0.30)$ & $1.05(0.92)$ & $0.74(0.32)$ & $0.82(0.37)$ & $0.68(0.29)$ \\
\hline 7 & AMS 08-L & $1.46(1.22)$ & $0.70(0.03)$ & $0.57(0.37)$ & $0.95(0.47)$ & $0.28(0.08)$ & $0.54(0.27)$ & $0.32(0.18)$ \\
\hline 8 & AMS 09-L & $2.15(0.76)$ & $0.46(0.31)$ & $1.46(1.07)$ & $0.44(0.29)$ & $0.55(0.31)$ & $1.21(0.96)$ & $0.61(0.31)$ \\
\hline 9 & AMS 10-L & $0.63(0.37)$ & $0.44(0.17)$ & $0.85(0.22)$ & $0.78(0.95)$ & $0.63(0.39)$ & $1.03(0.74)$ & $0.86(0.49)$ \\
\hline 9 & AMS 10T-L & $1.95(2.94)$ & $0.75(0.38)$ & $0.87(0.23)$ & $0.86(0.67)$ & $0.63(0.40)$ & $0.93(0.39)$ & $1.01(0.53)$ \\
\hline 10 & AMS 11-L & $1.58(1.10)$ & $0.71(0.29)$ & $0.90(0.28)$ & $0.52(0.28)$ & $0.56(0.31)$ & $1.19(0.99)$ & $0.51(0.30)$ \\
\hline 11 & AMS 12-L & $0.90(0.88)$ & $0.52(0.34)$ & $1.08(0.89)$ & $0.44(0.13)$ & $0.60(0.38)$ & $1.06(0.74)$ & $0.79(0.46)$ \\
\hline 12 & AMS 13-L & $2.37(2.10)$ & $0.50(0.25)$ & $1.58(1.48)$ & $0.45(0.36)$ & $0.41(0.24)$ & $0.94(0.75)$ & $0.38(0.20)$ \\
\hline 13 & AMS 14-L & & & & & & $0.94(0.70)$ & $0.41(0.20)$ \\
\hline 14 & AMS 15-L & & & & & & $1.06(0.73)$ & $0.42(0.21)$ \\
\hline 15 & Lysimeter-L & & & & & & & $0.43(0.09)$ \\
\hline 16 & Peat Pond-L & & & & & & & $0.25(0.03)$ \\
\hline 17 & W1 Dump-L & & & & & & & $0.34(0.06)$ \\
\hline 18 & B205-R & $1.27(0.77)$ & $0.41(0.12)$ & $0.88(0.36)$ & $0.73(0.35)$ & $0.32(0.15)$ & $0.32(0.06)$ & $0.33(0.24)$ \\
\hline 19 & B210-R & & $0.27(0.22)$ & $1.13(1.57)$ & $0.64(0.23)$ & $0.40(0.15)$ & $0.37(0.05)$ & $0.45(0.45)$ \\
\hline 20 & B213-R & 1.67 & $0.35(0.21)$ & $1.51(1.67)$ & $0.41(0.20)$ & $0.41(0.26)$ & $0.67(0.47)$ & $0.45(0.50)$ \\
\hline 21 & AH8R-R & & $0.58(0.38)$ & $0.59(0.40)$ & $0.29(0.27)$ & $0.20(0.13)$ & $0.29(0.05)$ & $0.35(0.23)$ \\
\hline 22 & AH3-R & $0.45(0.21)$ & $0.50(0.35)$ & $0.91(0.55)$ & $0.75(0.37)$ & $0.42(0.33)$ & $0.62(0.26)$ & $0.59(0.62)$ \\
\hline 23 & AH7-R & $0.72(0.36)$ & $0.45(0.13)$ & $1.36(0.93)$ & $0.61(0.12)$ & $0.40(0.09)$ & $0.64(0.34)$ & $0.48(0.17)$ \\
\hline 24 & PH2-R & $1.99(2.25)$ & $0.64(0.61)$ & $1.90(2.26)$ & $0.41(0.09)$ & $0.46(0.21)$ & $0.54(0.17)$ & $0.58(0.22)$ \\
\hline 25 & PH4-R & $0.86(0.26)$ & $0.56(0.30)$ & $1.18(0.61)$ & $0.79(0.38)$ & $0.38(0.06)$ & $0.43(0.15)$ & $0.69(0.37)$ \\
\hline 26 & PL1-R & $0.64(0.48)$ & $0.43(0.30)$ & $0.95(0.67)$ & $0.61(0.26)$ & $0.30(0.08)$ & $0.63(0.32)$ & $0.41(0.21)$ \\
\hline 27 & PL7-R & $0.72(0.39)$ & $0.42(0.20)$ & $0.74(0.46)$ & $0.57(0.16)$ & $0.22(0.05)$ & $0.44(0.23)$ & $0.48(0.15)$ \\
\hline 28 & JP212-R & & & & & $0.46(0.28)$ & $0.31(0.11)$ & $0.37(0.11)$ \\
\hline 29 & BM7-K & & & 0.38 & 0.28 & $0.36(0.27)$ & $0.84(0.94)$ & $0.28(0.18)$ \\
\hline 30 & BM10-K & & & & 0.21 & $0.28(0.20)$ & $0.49(0.40)$ & $0.26(0.20)$ \\
\hline 31 & BM11-K & & & & 0.23 & $0.24(0.16)$ & $0.58(0.50)$ & $0.35(0.30)$ \\
\hline 32 & NE7-K & & & & $0.15(0.04)$ & $0.24(0.18)$ & $0.54(0.42)$ & $0.21(0.12)$ \\
\hline 33 & NE10-K & & & & $0.16(0.02)$ & $0.33(0.24)$ & $0.30(0.03)$ & $0.25(0.15)$ \\
\hline 34 & NE11-K & & & & $0.41(0.08)$ & $0.28(0.06)$ & $0.36(0.06)$ & $0.23(0.14)$ \\
\hline 35 & SM7-K & & & 0.81 & $0.38(0.07)$ & $0.35(0.15)$ & $0.87(0.59)$ & $0.31(0.12)$ \\
\hline 36 & SM8-K & & & & $0.22(0.01)$ & $0.26(0.15)$ & $0.38(0.02)$ & $0.29(0.16)$ \\
\hline 37 & WF4-K & $1.50(1.00)$ & & & $0.24(0.09)$ & $0.31(0.10)$ & $0.96(0.94)$ & $0.63(0.58)$ \\
\hline
\end{tabular}

sented on these figures show slightly higher $\mathrm{HNO}_{3}$ values in winter compared to summer with the highest levels, in the centre of the bitumen exploitation and oil processing area near Fort McMurray and Fort McKay.

Monthly average $\mathrm{NH}_{3}$ concentrations were also highly variable in time and space (Fig. 3, Tab. 2). The highest $\mathrm{NH}_{3}$ value $\sim 9 \mu \mathrm{g} \mathrm{m}^{-3}$ occurred at site AMS 2 in August 2005, and occasional peaks $>6 \mu \mathrm{g} \mathrm{m}^{-3}$ occurred in various locations throughout the monitoring period. Ammonia measurements on a vertical gradient showed that at $0.5,1$ and $2 \mathrm{~m}$ above the ground concentrations were higher $\left(1.74 ; 1.81\right.$, and $1.96 \mathrm{\mu g} \mathrm{m}^{-3}$, respectively) than above the forest canopy $\left(1.39 \mathrm{\mu g} \mathrm{m}^{-3}\right)$. During the entire study the $\mathrm{NH}_{3}$ levels were higher in summer than in winter (Fig. 3, Tab. 2). This is clearly seen on the maps presenting $\mathrm{NH}_{3}$ distribution in winter 2007/2008 and summer 2008 (Figs 4c, d). Similarly as for $\mathrm{HNO}_{3}$, the highest $\mathrm{NH}_{3}$ concentrations occurred in the vicinity of Fort McMurray and Fort McKay. There was a trend of increasing $\mathrm{NH}_{3}$ concentrations in remote locations far away from the main oil exploitation activities; while the 2007 average concentration for those sites was $1.24 \mu \mathrm{g}$ $\mathrm{m}^{-3}$, for the 2008 summer it increased to $1.57 \mu \mathrm{g} \mathrm{m}^{-3}$ (Tab. 2).

\subsection{Uncertainty of prediction}

The uncertainty of prediction is described by the prediction standard error maps for both pollutants during winter 2007/2008 and summer $2008\left(\mathrm{HNO}_{3}\right.$ in Figs $5 \mathrm{a}, \mathrm{b}$ and $\mathrm{NH}_{3}$ in Figs $5 \mathrm{c}, \mathrm{d}$ ). These maps correspond with maps of spatial distribution of $\mathrm{HNO}_{3}$ (Figs $4 \mathrm{a}, \mathrm{b}$ ) and $\mathrm{NH}_{3}$ (Figs $4 \mathrm{c}, \mathrm{d}$ ). In winter, the average prediction standard error for $\mathrm{HNO}_{3}$ for the entire area was $\pm 0.32-0.34 \mu \mathrm{g} \mathrm{m}^{-3}$, while the lowest uncertainty was in the centre of the monitoring area and near individual monitoring sites. It was determined that relatively high levels of uncertainty existed around the central part of the monitoring activities within a radius of 25-35 km W and NW of Fort McKay and in a radius of $\sim 30 \mathrm{~km} \mathrm{~W}$ and $\mathrm{E}$ of Fort McMurray (Fig. 5a). In 
Tab. 2. Atmospheric $\mathrm{NH}_{3}$ concentrations $\left(\mu \mathrm{g} \mathrm{m}^{-3}\right.$ ) for summer and winter seasons during the 2005-2008 monitoring period expressed as average (and standard deviation). In general seasonal averages are based on six observations, average values without a standard deviation are based on one observation.

\begin{tabular}{|c|c|c|c|c|c|c|c|c|}
\hline \multirow[t]{2}{*}{ ID } & \multirow[t]{2}{*}{ Site name } & \multicolumn{2}{|c|}{2005} & \multicolumn{2}{|c|}{2006} & \multicolumn{2}{|c|}{2007} & \multirow{2}{*}{$\begin{array}{c}2008 \\
\text { Summer }\end{array}$} \\
\hline & & Summer & Winter & Summer & Winter & Summer & Winter & \\
\hline 1 & AMS 01-L & $1.49(1.45)$ & $1.05(0.66)$ & $1.25(0.61)$ & $2.32(2.24)$ & $1.95(0.63)$ & $0.71(0.27)$ & $1.39(0.48)$ \\
\hline 2 & AMS 02-L & $6.31(2.86)$ & $1.67(0.92)$ & $4.31(1.18)$ & $4.22(1.34)$ & $4.44(1.34)$ & $2.53(1.09)$ & $4.15(1.77)$ \\
\hline 3 & AMS 04-L & $2.64(0.69)$ & $1.32(0.30)$ & $3.12(1.47)$ & $1.63(0.37)$ & $3.65(1.12)$ & $1.64(0.87)$ & $3.97(1.28)$ \\
\hline 4 & AMS 05-L & $1.46(0.69)$ & $0.96(0.36)$ & $2.78(1.75)$ & $0.98(0.44)$ & $2.01(0.47)$ & $1.58(0.71)$ & $2.21(1.04)$ \\
\hline 5 & AMS 06-L & $1.62(1.13)$ & $1.59(0.21)$ & $2.74(1.44)$ & $1.99(0.70)$ & $2.11(0.32)$ & $1.72(0.57)$ & $2.56(0.75)$ \\
\hline 6 & AMS 07-L & $2.05(1.06)$ & $1.49(1.32)$ & $1.79(1.10)$ & $2.41(1.90)$ & $1.41(0.39)$ & $1.90(1.32)$ & $2.24(0.77)$ \\
\hline 7 & AMS 08-L & $0.91(0.91)$ & $0.87(0.34)$ & $0.96(0.56)$ & $3.02(2.29)$ & $1.82(1.76)$ & $0.62(0.22)$ & $1.79(0.98)$ \\
\hline 8 & AMS 09-L & $1.14(1.34)$ & $0.58(0.25)$ & $0.91(0.54)$ & $1.09(1.09)$ & $1.16(0.25)$ & $0.76(0.38)$ & $1.42(0.70)$ \\
\hline 9 & AMS 10-L & $1.94(2.01)$ & $1.32(0.81)$ & $1.67(1.77)$ & $1.46(1.30)$ & $1.40(0.31)$ & $0.73(0.28)$ & $1.28(0.76)$ \\
\hline 9 & AMS 10T-L & $1.67(0.77)$ & $1.30(0.59)$ & $2.10(1.67)$ & $1.63(2.17)$ & $1.55(0.53)$ & $0.80(0.38)$ & $1.61(0.89)$ \\
\hline 10 & AMS 11-L & $2.74(1.50)$ & $1.29(0.42)$ & $2.81(0.90)$ & $2.22(0.51)$ & $2.93(1.00)$ & $1.65(0.80)$ & $2.43(0.88)$ \\
\hline 11 & AMS 12-L & $1.56(0.57)$ & $1.24(0.89)$ & $1.13(0.65)$ & $1.21(0.13)$ & $2.69(1.48)$ & $0.98(0.38)$ & $3.46(1.37)$ \\
\hline 12 & AMS 13-L & $2.58(2.92)$ & $0.62(0.29)$ & $0.97(0.43)$ & $1.17(0.57)$ & $1.16(0.23)$ & $0.57(0.10)$ & $1.96(1.71)$ \\
\hline 13 & AMS 14-L & & & & & & $0.66(0.18)$ & $1.31(0.74)$ \\
\hline 14 & AMS 15-L & & & & & & $0.38(0.23)$ & $1.09(0.55)$ \\
\hline 15 & Lysimeter-L & & & & & & & $3.62(0.45)$ \\
\hline 16 & Peat Pond-L & & & & & & & $4.39(1.49)$ \\
\hline 17 & W1 Dump-L & & & & & & & $3.02(0.56)$ \\
\hline 18 & B205-R & $1.91(0.20)$ & $0.55(0.26)$ & $1.10(0.59)$ & $0.32(0.07)$ & $0.92(0.35)$ & $0.43(0.03)$ & $1.04(0.98)$ \\
\hline 19 & B210-R & 3.05 & $0.58(0.26)$ & $1.27(1.11)$ & $0.70(0.39)$ & $1.09(0.48)$ & $0.35(0.16)$ & $1.15(0.80)$ \\
\hline 20 & B213-R & 1.46 & $1.50(1.03)$ & $1.77(1.26)$ & $0.46(0.21)$ & $0.99(0.61)$ & $0.85(0.38)$ & $1.39(0.99)$ \\
\hline 21 & AH8R-R & & $0.44(0.22)$ & $1.11(0.64)$ & $0.84(0.43)$ & $0.76(0.22)$ & $0.32(0.04)$ & $1.63(1.25)$ \\
\hline 22 & AH3-R & $1.14(0.63)$ & $1.36(1.27)$ & $2.02(1.99)$ & $0.90(0.88)$ & $1.01(0.50)$ & $1.32(1.59)$ & $1.47(1.16)$ \\
\hline 23 & AH7-R & $1.14(0.35)$ & $0.61(0.19)$ & $0.95(0.54)$ & $0.85(0.28)$ & $1.42(0.18)$ & $0.63(0.35)$ & $1.65(0.96)$ \\
\hline 24 & PH2-R & $1.28(0.35)$ & $0.39(0.31)$ & $1.38(0.83)$ & $0.51(0.22)$ & $1.41(0.48)$ & $0.40(0.13)$ & $1.34(0.74)$ \\
\hline 25 & PH4-R & $1.83(1.54)$ & $0.43(0.19)$ & $1.75(1.45)$ & $0.78(0.33)$ & $1.07(0.26)$ & $0.52(0.34)$ & $1.66(1.05)$ \\
\hline 26 & PL1-R & $0.80(0.17)$ & $0.33(0.16)$ & $1.33(0.78)$ & $0.64(0.21)$ & $1.07(0.34)$ & $0.45(0.19)$ & $1.58(0.66)$ \\
\hline 27 & PL7-R & $1.62(1.14)$ & $0.78(0.28)$ & $1.09(0.76)$ & $0.58(0.28)$ & $1.32(0.64)$ & $0.33(0.06)$ & $1.34(0.60)$ \\
\hline 28 & JP212-R & & & & & $1.35(0.19)$ & $0.40(0.09)$ & $1.55(0.92)$ \\
\hline 29 & BM7-K & & & & 0.07 & $1.44(1.77)$ & $1.49(1.41)$ & $1.74(1.02)$ \\
\hline 30 & BM10-K & & & & $0.23(0.31)$ & $1.62(1.66)$ & $0.44(0.23)$ & $1.88(1.53)$ \\
\hline 31 & BM11-K & & & & 0.13 & $1.56(1.65)$ & $0.82(0.37)$ & $1.51(0.97)$ \\
\hline 32 & NE7-K & & & & $1.53(2.28)$ & $1.38(1.70)$ & $0.58(0.31)$ & $1.25(0.63)$ \\
\hline 33 & NE10-K & & & & $0.17(0.10)$ & $1.86(2.53)$ & $0.29(0.14)$ & $1.48(0.95)$ \\
\hline 34 & NE11-K & & & & $0.38(0.51)$ & $1.40(1.66)$ & $0.50(0.15)$ & $2.03(1.14)$ \\
\hline 35 & SM7-K & & & & $0.29(0.20)$ & $1.07(1.18)$ & $0.33(0.16)$ & $1.88(1.03)$ \\
\hline 36 & SM8-K & & & & $0.10(0.08)$ & $1.04(1.15)$ & $0.50(0.02)$ & $2.06(2.14)$ \\
\hline 37 & WF4-K & & & & $0.13(0.03)$ & $1.00(0.83)$ & $0.22(0.08)$ & $1.80(1.16)$ \\
\hline
\end{tabular}

summer, the average uncertainty for the entire area was lower than in winter at $\pm 0.16-0.18 \mu \mathrm{g} \mathrm{m}^{-3}$ with most of the monitoring area showing low levels of uncertainty. However, the area near Fort McMurray showed high levels of uncertainty up to $\pm 0.23-0.31 \mu \mathrm{g} \mathrm{m}^{-3}$ (Fig. $5 \mathrm{~b}$ ). In winter, the average prediction standard error for $\mathrm{NH}_{3}$ was $\pm 0.57-0.58 \mu \mathrm{g} \mathrm{m}^{-3}$ with lower levels of uncertainty near the individual sites and with relatively high levels of uncertainty up to $\pm 0.99-1.22 \mu \mathrm{g} \mathrm{m}^{-3}$ in the centre of the monitoring area in the vicinity of Fort McKay and Fort McMurray (Fig. 5c). In summer, the average prediction error for the entire area was $\pm 0.87-0.90 \mu \mathrm{g}$ $\mathrm{m}^{-3}$. Contrary to the winter values, the central, industrial area near Fort McKay and Fort McMurray had relatively low levels of uncertainty in summer (Fig. 5d).

\section{DISCUSSION}

Industrial activities related to the oil extraction and upgrading produce numerous air pollutants. Ammonia emissions can result from various sources such as aqueous mixture of floating agent containing $\mathrm{NH}_{3}$ used for separating and recovering bitumen from tar; second stage of upgrading of bitumen, called hydrotreating, in which $\mathrm{N}$ is removed as $\mathrm{NH}_{3}$; from tailing ponds which are contaminated with $\mathrm{NH}_{3}$ (WSE 2005). Additionally, emissions from trucks and other heavy equipment in the area produce elevated concentrations of $\mathrm{NO}_{\mathrm{x}}$, which undergo complex photochemical reactions with methane and other volatile organic compounds producing gaseous $\mathrm{HNO}_{3}$ (Seinfeld \& Pandis 1998).

Nitric acid concentrations during most of the study were elevated compared with the Alberta background concentration of $0.31 \mathrm{\mu g} \mathrm{m}^{-3}$ (Legge \& Krupa 1989). The highest recorded values $\sim 6-7 \mu \mathrm{g} \mathrm{m}^{-3}$ are comparable with the concentrations occurring on the western slopes of Sequoia \& Kings Canyon National Park in the Sierra Nevada, California (Bytnerowicz et al. 2002), and are much lower than those in the highly polluted areas in southern California (Bytnerowicz et al. 1999a). 

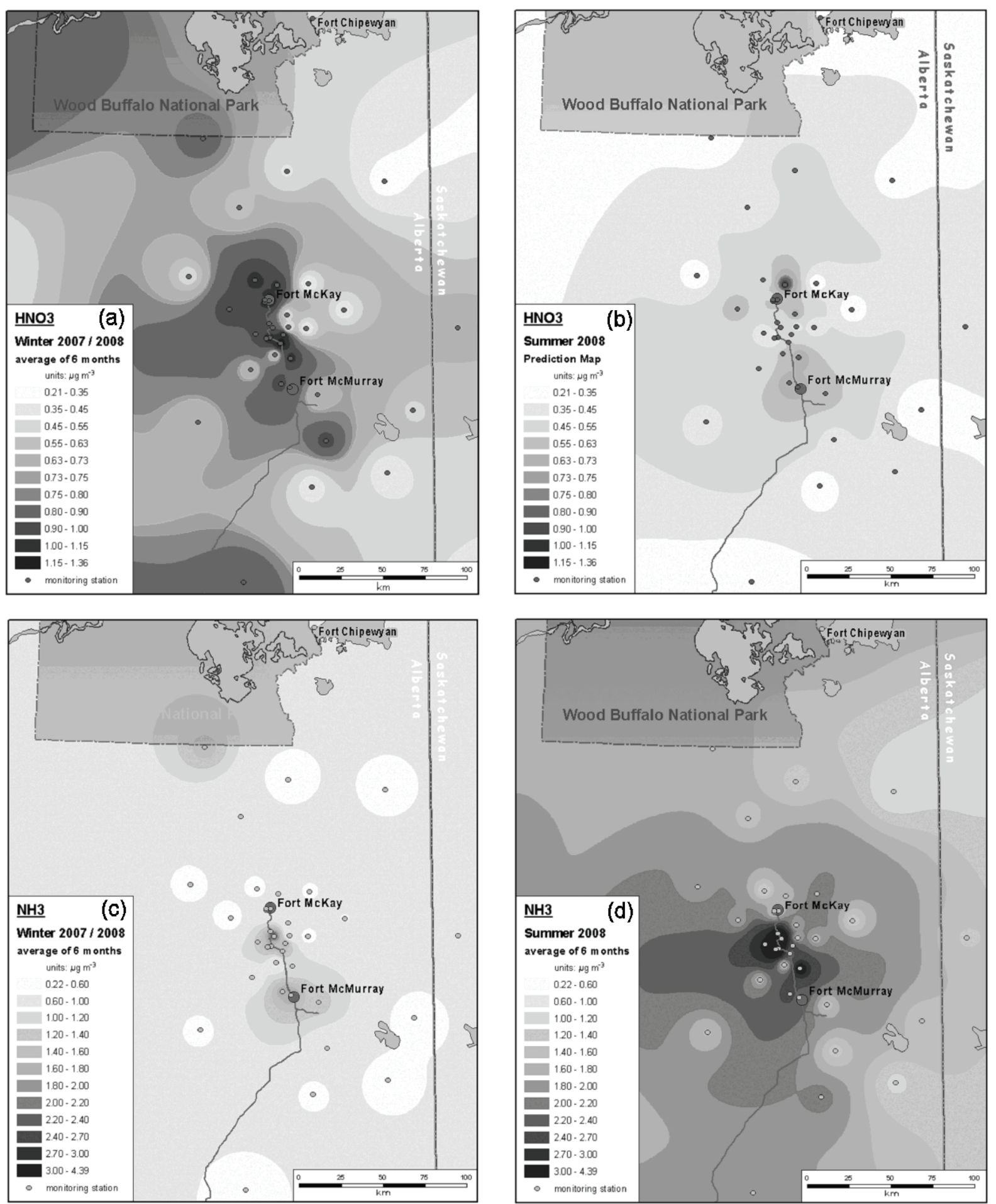

Fig. 4. Spatial distribution of $\mathrm{HNO}_{3}$ and $\mathrm{NH}_{3}$ concentrations in the Athabasca Oils Sands Region in 2008: (a) $\mathrm{HNO}_{3}$ in winter 2007/2008; (b) $\mathrm{HNO}_{3}$ in summer 2008 (c) $\mathrm{NH}_{3}$ in winter 2007/2008; (d) $\mathrm{NH}_{3}$ in summer 2008. 

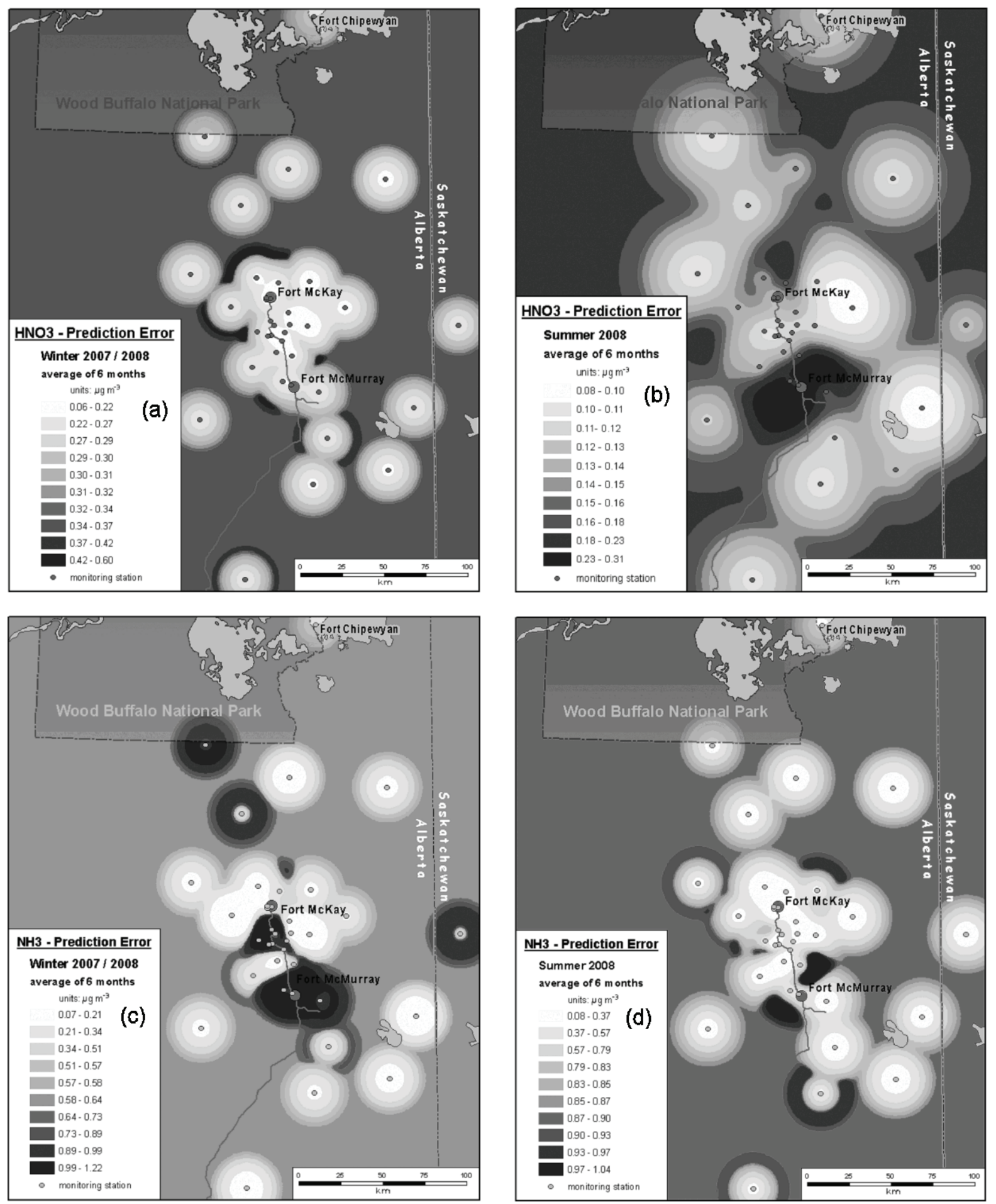

Fig. 5. Uncertainty analysis for $\mathrm{HNO}_{3}$ and $\mathrm{NH}_{3}$ distribution on the AOSR monitoring network expressed as the prediction error: (a) $\mathrm{HNO}_{3}$ in winter 2007/2008; (b) $\mathrm{HNO}_{3}$ in summer 2008 (c) $\mathrm{NH}_{3}$ in winter 2007/2008; (d) $\mathrm{NH}_{3}$ in summer 2008 . 
Low summer-season levels of $\mathrm{HNO}_{3}$ concentrations, which in many locations were close to the background values, could be partially caused by high atmospheric deposition of the pollutant during high physiological activity of vegetation (Hanson \& Lindberg 1991), and also possibly by titration of $\mathrm{HNO}_{3}$ by $\mathrm{NH}_{3}$ and formation of the aerosol $\mathrm{NH}_{4} \mathrm{NO}_{3}$ (Finlayson-Pitts \& Pitts 2000).

Highly elevated $\mathrm{NH}_{3}$ concentrations occurred during the entire study in numerous monitoring sites and significantly exceeded the long-term background mean concentration for Alberta of $0.26 \mu \mathrm{g} \mathrm{m}^{-3}$ (Krupa 2003), the value higher than $0.14 \mu \mathrm{g} \mathrm{m}^{-3}$ measured at the remote Niwot Ridge site of the Rocky Mountains in Colorado (Langford \& Fehsenfeld 1992). The highest recorded values of 6-9 $\mu \mathrm{g} \mathrm{m}^{-3}$ are higher than the longterm means for the agricultural areas of Alberta (Krupa 2003). These values are similar to the concentrations recorded in Sequoia \& Kings Canyon National Park downwind of the intensive agricultural activities of the California Central Valley (Bytnerowicz et al. 2002), or in Boulder, Colorado also affected by the agricultural emissions (Langford \& Fehsenfeld 1992). The high values reported from the western United States correspond well with the annual averages in the United Kingdom reaching $8 \mu \mathrm{g} \mathrm{m}^{-3}$ (Sutton et al. 2009). At present, it is not clear what potential sources of the elevated and increasing $\mathrm{NH}_{3}$ concentrations, especially in the remote sites, could be. The most obvious reason can simply be an expansion of the area of oil exploitation activities and higher intensity of its processing. This could lead to the increasing emissions from a variety of sources such as spills from the stack-installed $\mathrm{SO}_{2}$ scrubbers (Srivastava et al. 2004), emissions from the waste management activities and tailing ponds, emissions from the in situ oil exploitation or those associated with catalytic converters on mine fleet trucks. High levels of $\mathrm{NH}_{3}$ in remote areas could be caused by various phenomena such as biological decay, emissions from the smouldering phase of forest fires, volatilization of fertilizers from the nearby agricultural lands, etc. (Krupa 2003).

Summer season measurements on a vertical gradient under the forest canopy showed different distribution patterns for the two pollutants. Nitric acid levels above the canopy and at $2 \mathrm{~m}$ above the ground were similar and much higher than at 0.5 and $1 \mathrm{~m}$ above the ground. This seems to be an indication of the $\mathrm{HNO}_{3}$ deposition to ground vegetation and soils at forest floor. On the contrary, $\mathrm{NH}_{3}$ levels were higher underneath forest canopy than above it. This could indicate $\mathrm{NH}_{3}$ emissions from ground vegetation and soils. Clearly, a better understanding of a vertical distribution of various air pollutants within forest canopies, in forest openings, and in open areas such as bogs and fens in the AOSR is needed. This may help in improving monitoring networks and calculations of fluxes of air pollutants to different landscape categories.
Generally, the performance of the passive samplers during the study was satisfactory. However, some modifications of the monitoring procedures should be considered, such as improving the performance of samplers in winter conditions (effects of low temperatures and snow sometimes lead to wetting of filters or cracking of sampler components), or increasing the number of field replicates. Considering that in optimal field conditions in California both samplers performed very well, such improvements seem to be possible and should be explored. The monitoring network provided reliable results for most of the AOSR area. However, there were also areas which from a perspective of the calculated prediction error did not perform satisfactorily. Therefore, improvements in spatial coverage of the monitoring network are needed. The reliability maps show that some areas, even in the middle of the monitoring network, are under-represented and require additional monitoring sites. However, selection of such sites will not be easy considering big differences in the reliability of the monitoring network for various pollutants and during different seasons.

Long-term exposure to elevated concentrations of $\mathrm{N}$ gases and the resulting increased $\mathrm{N}$ deposition can have serious ecological implications and should be better understood in the AOSR. At the recorded levels, the direct toxic effects of $\mathrm{HNO}_{3}$ and $\mathrm{NH}_{3}$ on vascular plants are not likely to occur (Bytnerowicz et al. 1998, 1999 b). However, elevated $\mathrm{NH}_{3}$ levels may have potentially detrimental effects on lichen communities; recent results from Great Britain show that critical levels of $\mathrm{NH}_{3}$ for lichens should be set at $1 \mu \mathrm{g} \mathrm{m}^{-3}$ as an annual average (Cape et al. 2009). In addition, other negative effects related to the increased $\mathrm{N}$ deposition on forests and other ecosystems should be seriously considered (Laxton et al. 2010, this issue). Geostatistical surfaces of ambient concentrations of the two gases resulting from this study, their deposition velocity values obtained from literature (Zhang et al. 2003, 2009), and information on vegetation cover obtained from remote sensing (such as MODIS images) could be utilized for generation of the GIS-based maps of atmospheric $\mathrm{N}$ dry deposition. Such maps together with information on $\mathrm{N}$ wet deposition could be used for the evaluation of ecological risks from atmospheric $\mathrm{N}$ in the AOSR (Laxton et al. 2010, this issue). It seems that potential risks could be much higher from $\mathrm{NH}_{3}$ considering its high ambient concentrations, proportionally more $\mathrm{N}$ contained in the $\mathrm{NH}_{3}$ molecule, and similar deposition velocities of the two gases (Lovett 1994). The resulting increased $\mathrm{N}$ deposition caused by elevated ambient $\mathrm{NH}_{3}$ and $\mathrm{HNO}_{3}$ concentrations could include shifts in $\mathrm{N}$ and carbon allocation, increase ecosystem biomass production, and change of species composition (Fenn et al. 2003; Magnani et al. 2008). A better understanding of potential threats by elevated levels of $\mathrm{N}$ pollutants and $\mathrm{N}$ deposition is needed for a sound assessment of 
ecological risks in the AOSR and the surrounding area. Such information is essential for the ecologicallyresponsible continuation of the present industrial activities and planned future expansion of oil exploitation and processing in the AOSR.

\section{CONCLUSIONS}

Information on spatial and temporal distribution of $\mathrm{N}$ pollutants is essential for understanding their potential effects on ecosystems health and sustainability in the areas affected by the oil recovery and processing. Multi-year monitoring of $\mathrm{HNO}_{3}$ and $\mathrm{NH}_{3}$ showed that concentrations of these pollutants were elevated and highly variable in space and time. Ammonia concentrations were higher, contributing more $\mathrm{N}$ for atmospheric dry deposition and potentially posing a more serious thread to forests and other ecosystems of the AOSR than $\mathrm{HNO}_{3}$.

For a better understanding of a spatial distribution of $\mathrm{HNO}_{3}$ and $\mathrm{NH}_{3}$ in the AOSR, further refinement of the monitoring network is needed. There is also a need for acquiring data on spatial and temporal concentrations of $\mathrm{NO}_{\mathrm{x}}$, particulate $\mathrm{NH}_{4}{ }^{+}$and $\mathrm{NO}_{3}{ }^{-}$as well as organic $\mathrm{N}$ compounds in order to have a better understanding of atmospheric $\mathrm{N}$ deposition levels and effects. This also includes better characterization of the air pollution distribution and atmospheric deposition patterns on vertical gradients in forest canopies, in forest openings and along forest edges.

Development of empirical models of dry $\mathrm{N}$ deposition to forests and other ecosystems based on the results of air pollution monitoring and establishment of critical loads for nutrient $\mathrm{N}$ and acidity is recommended. Such models and GIS-based maps of $\mathrm{N}$ deposition, $\mathrm{N}$ critical levels and $\mathrm{N}$ critical loads are needed for understanding potential ecological risks from air pollution in the AOSR. One of the first steps towards that could be generation of maps showing exceedances of critical levels of $\mathrm{NH}_{3}$ for lichens.

\section{ACKNOWLEDGEMENTS}

The study was sponsored by the Wood Buffalo Environmental Association, Fort McMurray, Alberta, Canada. The authors thank Carna MacEachern, Darrell Martindale and David Spink for their continuous support of this study; Allan Legge and Kevin Percy for advice; Veronica Chisholm, Cynthia Huppie and Dorothy Brown for assistance with field monitoring activities. Constructive comments and suggestions from the anonymous reviewers and editorial guidance provided by Julian Aherne and Pat Shaw are greatly appreciated.

\section{REFERENCES}

Bytnerowicz, A., T. Dueck \& S. Godzik. 1998. Nitric oxide, nitrogen dioxide, nitric acid vapor and ammonia. In: R. Flagler (Ed.), Recognition of Air Pollution Injury to
Vegetation: a Pictorial Atlas. Air \& Waste Management Association, Pittsburgh, PA: 5-1 through: 5-17.

Bytnerowicz, A., M. Fenn, P. Miller \& M. Arbaugh. 1999a. Wet and dry pollutant deposition to the mixed conifer forest. In: P.R. Miller and J. McBride (Eds), Oxidant Air Pollution Impacts in the Montane Forests of Southern California: The San Bernardino Mountains Case Study. Springer, Ecological Series 134, New York: 235-269.

Bytnerowicz, A., P. Padgett, K. Percy, M. Krywult, G. Riechers \& J. Hom. 1999b. Direct effects of nitric acid on forest vegetation. In: P.R. Miller and J. McBride (Eds), Oxidant air pollution impacts in the montane forests of Southern California: the San Bernardino mountains case study. Springer, Ecological Series 134, New York: 270287.

Bytnerowicz, A., M. Tausz, R. Alonso, D. Jones, R. Johnson \& N. Grulke. 2002. Summer-time distribution of air pollutants in Sequoia National Park, California. Environ. Pollut., 118: 187-203.

Bytnerowicz, A., M.J. Sanz, M.J. Arbaugh, P.E. Padgett, D.P. Jones \& A. Davila. 2005. Passive sampler for monitoring ambient nitric acid $\left(\mathrm{HNO}_{3}\right)$ and nitrous acid $\left(\mathrm{HNO}_{2}\right)$ concentrations. Atmos. Environ., 39: 2655-2660.

Cape, J.N., L.J. Van Der Eerden, L.J. Sheppard, I.D. Leith \& M.A. Sutton. 2009. Evidence for changing the critical level for ammonia. Environ. Pollut., 157: 1033-1037.

Charpentier, A.D., J.A. Bergerson \& H.L. McLean. 2009. Understanding the Canadian oil sands industry's greenhouse gas emissions. Environ. Res. Lett., 4: 1-11.

Chiles, J.-P. \& P. Delfiner. 1999. Geostatistics-Modeling Spatial Uncertainty. Wiley Series in Probability \& Statistics, New York: 720 pp.

Fenn, M.E., J.S. Baron, E.B. Allen, H.M. Rueth, K.R. Nydick, L. Geiser, W.D. Bowman, J.O. Sickman, T. Meixner, D.W. Johnson \& P. Nietlich. 2003. Ecological effects of nitrogen deposition in the western United States. Biosci., 53: 404-420.

Finlayson-Pitts, B.J. \& J.N. Pitts Jr. 2000. Chemistry of the upper and lower atmosphere. Academic Press, San Diego: $969 \mathrm{pp}$.

Gu, G., Z. Xu, K. Nandakumar \& J.H. Masliyah. 2002. Influence of water-soluble and water-insoluble natural surface active components on the stability of water-intoluene-diluted bitumen emulsion. Fuel, 81: 1859-1869.

Hanson, P.J. \& S.E. Lindberg. 1991. Dry deposition of reactive nitrogen compounds: a review of leaf, canopy and non-foliar measurements. Atmos. Environ., 25A: 16151634.

Johnston, K., J. Ver Hoef, K. Krivoruchko \& N. Lucas. 2001. Using ArcGIS Geostatistical Analyst. ESRI, Redlands, California.

Kean, S. 2009. Eco-alchemy in Alberta. Science, 326: 10521055.

Kelly, E.N., J.W. Short, D.W. Schindler, P.V. Hodson, M. Ma, A.K. Kwan \& B.L. Fortin. 2009. Oil sands development contributes polycyclic aromatic compounds to the Athabasca River and its tributaries. PNAS, DOI: 10.1073/pnas.0912050106.

Koutrakis, P., C. Sioutas, S.T. Ferguson, J.M. Wolfson, J.D. Mulik \& R.M. Burton. 1993. Development and evaluation of a glass honeycomb denuder/filter pack system to collect atmospheric gases and particles. Environ. Sci. Technol., 27: 2497-2501.

Krupa, S.V. 2003. Effects of atmospheric ammonia $\left(\mathrm{NH}_{3}\right)$ on terrestrial vegetation: a review. Environ. Pollut., 124: 179221.

Krupa, S.V. \& A.H. Legge. 2000. Passive sampling af ambient gaseous air pollutants: an assessment from an ecological perspective. Environ. Pollut., 107: 31-45.

Kunzig, R. 2009. The Canadian oil boom. National Geographic, 215: 34-59. 
Langford. A.O. \& F.C. Fehselfeld. 1992. Natural vegetation as a source or sink for atmospheric ammonia: a case study. Science, 255: 581-583.

Laxton, D.L., S.A. Watmough, J. Aherne \& J. Straker. 2010. An assessment of nitrogen saturation in Pinus banksiana plots in the Athabasca Oil Sands Region, Alberta. $J$. Limnol., 69(Suppl. 1): 171-180. DOI: 10.3274/JL10-69S1-17.

Legge, A.H. \& S.V. Krupa. 1989. Air quality at a high elevation, remote site of Western Canada. In: R.K. Olson \& A.S. Lefohn (Eds), Transactions of the symposium on: Effects of air pollution on western forests. Anaheim, California, 29-30 June 1989. Air and Waste Management Association, Pittsburgh, PA, USA: 193-206.

Lovett, G.M. 1994. Atmospheric deposition of nutrients and pollutants in North America: an ecological perspective. Ecol. Appl., 4: 629-650.

Magnani, F., M. Mencuccini, M. Borghetti, F. Berninger, S. Delzon, A. Grelle, P. Hari, P.G. Jarvis, P. Kolari, A.S. Kowalski, H. Lankreijer, B.E. Law, A. Lindroth, D. Loustau, G. Manca, J.B. Moncrieff, V. Tedeschi, R. Valentini \& J. Grace. 2008. Reply, Nature, 451: E3-E4.

Roadman, M.J., J.R. Scudlark, J.J. Meisinger \& W.J. Ullman. 2003. Validation of Ogawa passive samplers for the determination of gaseous ammonia concentrations in agricultural settings. Atmos. Environ., 37: 2317-2325.
Seinfeld, J.H. \& S.N. Pandis. 1998. Atmospheric chemistry and physics. John Wiley \& Sons, Inc., New York: 1326 pp.

Shrivastava, R.K., W. Jozefowicz \& C. Singer. 2004. $\mathrm{SO}_{2}$ scrubbing technologies: a review. Environ. Prog., 20: 219-228.

Sutton, M.A., P.A. Wolseley, I.D. Leith, N. van Dijk, Y.S. Tang, P.W. James, M.R. Theobald \& C. Whitfield. 2009. Estimation of the ammonia critical levels for epiphytic lichens based on observations at farm, landscape and national scales. In: M. Sutton, S. Reis, S. M. \& H. Bakker (Eds), Atmospheric ammonia. Springer Science \& Business Media: 71-86.

U.S. EPA. 2008. Integrated Science Assessment (ISA) for oxides of nitrogen and sulfur-ecological criteria (final Report). EPA/600/R-08/082F. U.S. Environmental Protection Agency, National Center for Environmental Assessment-RTP Division, Office of Research and Development, Research Triangle Park, NC.

WSE. 2006. Engineering Data Sheet. Water Smart Environmental, Inc., Publication 5099.

Zhang, L., J.R. Brook \& R. Vet. 2003. A revised parameterization for gaseous dry deposition in air-quality models. Atmos. Chem. Phy., 3: 2067-2082.

Zhang, L., R. Vet, J.M. O'Brien, C. Mihele, Z. Liang \& A. Wiebe. 2009. Dry deposition of individual nitrogen species at eight Canadian rural sites. J. Geophys. Res., 114: D02301. 